\author{
Andrzej Raczyk, Sylwia Dołzbłasz \\ Uniwersytet Wrocławski \\ e-mails: andrzej.raczyk@uwr.edu.pl; sylwia.dolzblasz@uwr.edu.pl
}

\title{
CELE I BARIERY WSPÓLPRACY TRANSGRANICZNEJ NA POGRANICZU POLSKO-NIEMIECKIM PO 2020 R. W ŚWIETLE DOKUMENTÓW STRATEGICZNYCH I PLANISTYCZNYCH
}

\section{AIMS AND BARRIERS FOR THE TRANSBORDER CO-OPERATION POLICY IN THE POLISH-GERMAN BORDERLAND AFTER 2020 IN THE LIGHT OF STRATEGIC AND PLANNING DOCUMENTS}

DOI: $10.15611 / \mathrm{pn} .2018 .537 .07$

JEL Classification: R58

Streszczenie: Celem pracy była identyfikacja najważniejszych problemów i możliwości rozwoju współpracy transgranicznej na pograniczu polsko-niemieckim w nowym okresie programowania UE 2021-2027. Główną przesłanką badań była dyskusja nad kształtem polityki współpracy w kontekście zasadniczej poprawy jej efektywności oraz ograniczonych środków finansowych przeznaczonych na jej realizację. Podstawą opracowania była analiza dokumentów strategicznych i planistycznych w odniesieniu do polskiej i niemieckiej części pogranicza na poziomie krajowym i regionalnym. Badania pokazały, że na obszarze polsko-niemieckiego pogranicza brak jednej, wspólnej i uszczegółowionej docelowej wizji rozwoju współpracy transgranicznej. Istniejące dokumenty strategiczne oraz planistyczne były głównie złożeniem elementów istotnych z punktu widzenia poszczególnych regionów/krajów związkowych, a nie spójności całego pogranicza. Brak wspólnego planowania strategicznego stanowi jeden z powodów trudności w określeniu efektu transgranicznego oraz pomiaru skuteczności interwencji.

Słowa kluczowe: polityka spójności, współpraca transgraniczna, strategia rozwoju, pogranicze polsko-niemieckie.

Summary: The aim of the paper is to identify the most important problems and possibilities for the transborder co-operation development in the Polish-German borderland in the EU 2021-2017 programming period. The main premise of the study was a discussion on the future of the transborder co-operation in the context of its effectiveness substantial improvement and limited financial support. The study was based on the analysis of the existing strategic and planning documents implemented in the Polish and German border area on the regional and local level. The study shows that the Polish-German borderland lacks one, common and detailed (precise) target vision of transborder co-operation development. The strategic and 
planning documents formulated so far have been the composition of elements important from the point of view of individual regions/federal states, and not the cohesion of the borderland. Lack of common strategic planning constitutes one of the problems when assessing the actual transborder effect and the measurement of the effectiveness of intervention.

Keywords: cohesion policy, transborder co-operation, development strategy, Polish-German borderland.

\section{Wstęp}

Zagadnienie kształtowania rozwoju obszarów pograniczy stanowi jeden z istotnych problemów polityki spójności Unii Europejskiej. Program Interreg jest przy tym najważniejszym czynnikiem kształtującym struktury oraz charakter współpracy transgranicznej w Polsce.

Pogranicze polsko-niemieckie, rozumiane jako obszar po obu stronach granicy, charakteryzuje się wieloletnim i bogatym doświadczeniem w realizacji współpracy transgranicznej. Przyniosła ona wiele pozytywnych zmian w rozwoju pogranicza m.in. w zakresie pogłębiania kontaktów międzyludzkich, rozwoju turystyki, rozwiązywania problemów środowiskowych, poprawy wyposażenia infrastrukturalnego oraz poziomu bezpieczeństwa itd. Jednocześnie jednak nadal realizacja współpracy stawia szereg wyzwań wiążących się z poprawą jej efektywności, zwiększeniem transgranicznego oddziaływania realizowanych projektów oraz silniejszej integracji wspólnego obszaru pogranicza.

Celem opracowania była identyfikacja najważniejszych problemów i możliwości rozwoju współpracy transgranicznej w nowej perspektywie polityki spójności. Zasadniczym wyzwaniem jest przy tym poprawa efektów integracji pogranicza polsko-niemieckiego przy spodziewanym ograniczeniu środków finansowych przeznaczonych na jej realizację. Podstawą opracowania była analiza polskich i niemieckich dokumentów strategicznych i planistycznych mających wpływ na współpracę transgraniczną. Na jej podstawie sformułowano najważniejsze wnioski i rekomendacje dla kształtowania współpracy po roku 2020.

\section{Podstawy wspólpracy transgranicznej}

Znaczenie współpracy transgranicznej znalazło swoje odzwierciedlenie w Traktacie o funkcjonowaniu Unii Europejskiej [2012]. Podkreślono w nim wyzwania, przed którymi stoją regiony przygraniczne, i wskazano, że UE powinna zwracać szczególną uwagę na te regiony przy opracowywaniu działań prowadzących do wzmocnienia spójności gospodarczej, społecznej i terytorialnej.

Ogólnym celem działań realizowanych w ramach współpracy transgranicznej było stworzenie sytuacji, w której granice państwowe nie będą przeszkodą w zrównoważonym rozwoju oraz integracji obszaru Europy. Izolacja obszarów przy- 
granicznych ma podwójną naturę: $\mathrm{z}$ jednej strony, granice oddzielają od siebie społeczności przygraniczne w sferze gospodarczej, społecznej, kulturalnej oraz przeszkadzają w spójnym zarządzaniu ekosystemami, z drugiej natomiast obszary przygraniczne często stanowią obszary peryferyjne (w wyniku np. zaniedbywania ich rozwoju przez władze centralne) w danym państwie. Procesy integracyjne zachodzące w UE, w tym kształtowanie się jednolitego rynku oraz unii gospodarczo-walutowej, mogą być źródłem silnych impulsów rozwojowych, sprzyjających dynamizacji rozwoju terenów przygraniczy. Jednocześnie obserwowane współcześnie wyraźne procesy o dezintegracyjnym charakterze powodują konieczność ich uwzględnienia w przyszłym kształtowaniu polityki współpracy.

Zasadność realizacji współpracy transgranicznej wynika z faktu, że ponad jedna trzecia obywateli UE mieszka i pracuje w europejskich regionach przygranicznych [People-to-people 2017]. Granice mają więc bezpośredni i pośredni wpływ na ich życie, przy czym skala tego wpływu, jakkolwiek w powszechnej świadomości niedoceniana, jest bardzo duża. Istnieje w zasadzie zgodność, że regiony przygraniczne rozwijają się wolniej niż pozostałe [Territories with specific geographical features 2009], a wpływ przeszkód granicznych na ograniczenie poziomu PKB i zatrudnienia wynosi ok. 8\% [Boosting growth 2017]. Bariery rozwojowe wynikające $\mathrm{z}$ istnienia granicy i mogące być niwelowane w ramach współpracy transgranicznej obejmują:

- infrastrukturę (bariery fizyczne),

- transport i rynek pracy (integracja rynków),

- innowacje i działalność gospodarczą (konkurencyjność),

- świadczenie usług na obszarach miejskich (miejskie usługi transgraniczne),

- edukację, szkolenia i działalność społeczną (kapitał ludzki i społeczny),

- zasoby naturalne (w tym obszary chronione).

Współpraca transgraniczna okazała się dotychczas najskuteczniejszym narzędziem przezwyciężania bariery granic, integracji obszarów przygranicznych i poprawy jakości życia obywateli regionów granicznych [People-to-people 2017]. Zgodnie z tym Stanowisko Komisji Polityki Spójności Terytorialnej i Budżetu UE [Przyszłość polityki spójności 2016] wskazuje znaczenie wymiaru terytorialnego polityki spójności i potrzebę kontynuacji współpracy transgranicznej. Podobne stanowisko wyraził rząd Niemiec [Comments by the German 2017] oraz rząd Polski [Wstępne stanowisko 2017].

Problemami współpracy transgranicznej na pograniczu polsko-niemieckim zajmowano się: w ujęciu kompleksowym [m.in. Ciok 1990; 2004], w zakresie współpracy podmiotów gospodarczych [m.in. Stryjakiewicz 1998; Gruchman i in. 2002; Raczyk $\mathrm{i}$ in. 2012], powiązań ekonomicznych [m.in. Powęska 2016], w kontekście planowania strategicznego i przestrzennego [m.in. Stasiak, Miros (red.) 1993; Węcławowicz i in. 2006], współpracy euroregionalnej [m.in. Przybyła 1995; Strahl, Obrębalski 1995; Obrębalski 2011]. Jakkolwiek obserwować można dużą liczbę badań obszarów pograniczy, to jednak nadal odczuwalny jest niedostatek ujęć obejmujących obszary położone po obu stronach granic, w tym szczególnie odnoszących się do perspektyw ich rozwoju. 


\section{Współpraca transgraniczna a dokumenty strategiczne i planistyczne}

Strategia na rzecz Odpowiedzialnego Rozwoju [2017] wskazała konieczność uwzględniania wymogu podejścia zintegrowanego. Powoduje to, że podejmowane działania powinny być realizowane w sposób zintegrowany, z uwzględnieniem specyfiki ponadregionalnej, regionalnej, lokalnej i obszarów funkcjonalnych. Stąd współpraca terytorialna powinna stanowić istotne uzupełnienie polityki regionalnej województw oraz polityk sektorowych kraju w wymiarach, które nie są możliwe do realizacji w ich ramach (np. regionalnych programów operacyjnych), m.in. zintegrowane kształtowanie transgranicznych obszarów funkcjonalnych, budowa transgranicznych powiązań społecznych i gospodarczych, przeciwdziałanie transgranicznym zagrożeniom, niwelowanie funkcji granicy jako bariery (np. fizycznej, mentalnej, ekonomicznej). Jednocześnie jednak postulowany wymóg integracji wymaga, by miała ona odrębną, kompleksową postać, uwzględniając wszystkie aspekty współpracy transgranicznej, a nie jej rozproszenie, np. w obrębie poszczególnych programów sektorowych czy regionalnych. Postulowany efekt synergii najłatwiej osiągnąć, nadając polityce współpracy charakter „,plastra” spajającego działania realizowane w układach regionalnych i subregionalnych. Wymaga to pewnej modyfikacji stosowanego dotychczas podejścia, w którym interwencja dokonywana była głównie z punktu widzenia potrzeb krajowych, polskich lub niemieckich (zgodnie z zasadą: co dobre dla jednej ze stron, dobre dla całego pogranicza), a nie potrzeb regionu transgranicznego. W praktyce bowiem podejście takie nie zawsze prowadziło do pojawienia się efektu synergii i osłabiało skuteczność interwencji. Wynikało to głównie z niedostatku wiedzy odnośnie do tego, co jest najbardziej pożądane, trwałe i wnoszące największą wartość dodaną dla całego obszaru pogranicza.

Należy przy tym uwzględnić fakt, że pogranicze polsko-niemieckie posiada jedną z większych w skali UE liczbę barier wynikających z obecności granicy [Collecting solid evidence 2016].

Bardzo duże znaczenie dla kształtowania polityki współpracy po obu stronach granicy mają regionalne (landowe) dokumenty strategiczne i planistyczne [Strategia 2010; Strategia 2012; Strategia 2013; Landesentwicklungsplan 2013; Landesentwicklungsplan 2017; Landesraumentwicklungsprogramm 2016]. W wymiarze syntetycznym odnoszą się one do pograniczy na poziomie diagnostycznym oraz formułowanych celów polityki regionalnej. Obejmują bardzo różny wachlarz problemów i na różnym poziomie szczegółowości odnoszą się do kwestii współpracy transgranicznej. Można przy tym zauważyć, że z reguły w warstwie diagnostycznej podkreślają bardzo wiele zjawisk i procesów zachodzących w wymiarze transgranicznym, z których w warstwie celów zaledwie niewielka część ma szczegółowe odzwierciedlenie.

Istotne problemy wiążące się z rozwojem współpracy transgranicznej wynikają z odmiennego systemu planowania strategicznego po obu stronach granicy. Dotyczy 
to m.in. zakresu tematycznego, układu treści czy poziomu szczegółowości dokumentów funkcjonujących po polskiej oraz niemieckiej stronie. Utrudnia to ich ewentualne zestawianie. Różny jest także stan aktualizacji oraz horyzont czasowy tych dokumentów.

Jakkolwiek w praktyce planowania strategicznego wypracowano mechanizmy konsultacji i uzgodnień z partnerami po drugiej stronie granicy, to jednak na obszarze pogranicza realizowanych jest sześć różnych polityk rozwoju regionalnego (trzy wojewódzkie i trzy landowe), które w niewielkim stopniu odnoszą się bezpośrednio do obszarów najsilniej związanych z granicą, a raczej skierowane są na wzmacnianie regionalnych rdzeni rozwojowych. Z punktu widzenia rozwoju relacji współpracy najbardziej skutecznym mechanizmem koordynacji mogłyby się stać wspólne dokumenty strategiczno-planistyczne obszarów pogranicza.

Wpływ realizowanych polityk regionalnych na poziomie polskich województw oraz niemieckich krajów związkowych na kształtowanie współpracy był dotychczas względnie niski. Polityki te w zbyt małym stopniu przekładały się na realny zakres współpracy, kształtowanie układu instytucjonalnego czy kształtowanie węzłów współpracy (w wielu wypadkach w ogóle się do tych kwestii nie odnosiły).

Kompleksowy system transgranicznych dokumentów strategicznych obejmujący pogranicze polsko-niemieckie istniał w ramach euroregionów. Należy przy tym podkreślić, że określony tam zakres współpracy znacząco wykraczał poza katalog działań możliwych do realizacji w ramach Funduszy Małych Projektów realizowanych w programach Interreg. Miał więc niejednokrotnie charakter postulatywny.

Jakkolwiek zakres tematyczny powyższych dokumentów był bardzo obszerny, to na potrzeby realizacji polityki współpracy w wielu wypadkach wskazane byłoby jego doprecyzowanie. Zalecane byłoby także ich ujednolicenie i uzupełnienie zarówno z punktu widzenia zawartości merytorycznej, jak i elementów formalnych, m.in. o kwestie związane z monitorowaniem jego realizacji. Można przy tym zauważyć duże problemy związane z opracowaniem szczegółowej diagnozy sytuacji społeczno-ekonomicznej i przestrzennej, wynikające z braku porównywalnych danych statystycznych nawet w zakresie elementarnych wskaźników sfery gospodarczej czy społecznej (np. rynek pracy, przedsiębiorczość). Niedostatki informacyjne w zakresie transgranicznej statystyki publicznej stanowią jedną z istotniejszych barier formułowania trafnych i dostosowanych do potrzeb mieszkańców dokumentów strategicznych i planistycznych (zarówno w wymiarze lokalnym, jak i regionalnym). Stąd niezbędne jest podjęcie działań intensyfikujących współpracę urzędów statystycznych po obu stronach granicy oraz związanych z wykonaniem opracowań analityczno-studialnych zorientowanych na identyfikację tych potrzeb.

Jednym z elementów skutecznej polityki regionalnej jest koordynacja i spójność działań na obszarze wykraczającym poza terytorialne ramy województwa. Strategia Rozwoju Polski Zachodniej 2020 [2014] obejmuje przy tym przede wszystkim zagadnienia współpracy między województwami oraz promuje działania poszerzające możliwości rozwoju partnerskich relacji między nimi. Dotyczy więc perspektywy 
makroregionu, natomiast siłą rzeczy pomija kontekst pogranicza, jakkolwiek podkreśla jego znaczenie. W efekcie postulowany w niej zakres interwencji służy głównie poprawie ponadregionalnej spójności w układzie województw objętych programem, a nie spójności pogranicza. Dlatego też jej przydatność dla kształtowania współpracy z Niemcami jest ograniczona.

Efektem działań realizowanych równocześnie na rzecz rozwoju planistycznego polskiej części pogranicza było opracowanie Studium integracji przestrzennej polskiej części pogranicza Polski i Niemiec [2012]. Zakres przestrzenny Studium obejmował województwa dolnośląskie, lubuskie i zachodniopomorskie. Określono w nim wiele ważnych dla przygranicza kierunków rozwoju przestrzennego, dokonano tego jednak głównie z punktu widzenia rozwoju poszczególnych regionów. W efekcie nie ma ono charakteru transgranicznego. Ponieważ stanowi dokument uzgodniony w wymiarze ponadregionalnym, może być traktowane jako punkt wyjścia do kształtowania polsko-niemieckiej polityki współpracy i prezentujący polskie potrzeby w zakresie rozwoju przestrzennego.

Jednym z niewielu wspólnych, transgranicznych dokumentów o charakterze strategicznym jest Wspólna Koncepcja Przyszłości dla polsko-niemieckiego obszaru powiazań [2016]. Obejmuje ona terytorium znacząco wykraczające poza obszar wsparcia w ramach współpracy transgranicznej (cztery województwa po polskiej, cztery kraje związkowe po niemieckiej stronie). Koncepcja ma charakter makroskalowy, może więc stanowić dobry punkt wyjścia do planowania strategicznego zawężonego do obszaru wsparcia. Jakkolwiek trafnie precyzuje liczne ważne wyzwania współpracy, to jednak ze względu na zakres przestrzenny ma ograniczoną przydatność do implementacji dla poziomu poszczególnych programów, ponieważ ma głównie wymiar kierunkowy (ogólny), wymagający dalszego uszczegółowienia. Nie porusza kwestii np. transgranicznych obszarów funkcjonalnych, transgranicznych zjawisk i procesów mogących stanowić istotną przesłankę rozwoju itd.

Należy mieć na uwadze, że zgodnie z zapisami Koncepcji Przestrzennego Zagospodarowania Kraju 2030 [2012] jednym z procesów, którym powinny podlegać polityki publiczne w UE, jest przechodzenie od podejścia sektorowego do zintegrowanego podejścia terytorialnego (integrated territorial approach). Charakteryzuje się ono ukierunkowaniem na wykorzystanie endogenicznych potencjałów terytoriów określonych funkcjonalnie. W Koncepcji określono także, że obszary funkcjonalne powinny być uwzględniane jako element planowania przestrzennego oraz społeczno-gospodarczego na poziomach krajowym, regionalnym, lokalnym, a tam gdzie jest to zasadne, stanowić odrębną kategorię planistyczną. Stąd dla potrzeb planowania współpracy transgranicznej istnieje możliwość wskazania oddzielnie obszarów funkcjonalnych, nawet $\mathrm{w}$ sytuacji, gdy nie są one wymienione w planach regionalnych. Ponadto jednym z istotnych zapisów zawartych w KPZK jest zalecenie opracowania strategii i planów rozwoju dla obszarów położnych po obu stronach granicy. 
Współpraca transgraniczna, a zwłaszcza projekty typu People-to-people (P2P), stanowi jeden z najbardziej konkretnych przykładów szczególnych korzyści i wartości dodanej w codziennym życiu obywateli. W świetle obecnej sytuacji w UE (rosnący nacjonalizm, procesy dezintegracyjne, kryzys migracyjny, trudności gospodarcze i finansowe) polityka współpracy powinna odpowiadać istniejącym wyzwaniom. Z badań [People-to-people 2017] wynika, że w programach Interreg najlepsze wyniki jakościowe zależą od różnorodnych, ponadgranicznych działań ściśle dostosowanych do potrzeb, przy jednoczesnym zaangażowaniu obywateli, władz lokalnych i organizacji społeczeństwa obywatelskiego.

\section{Zakończenie}

Na obszarze pogranicza polsko-niemieckiego brak jest jednej, wspólnej i uszczegółowionej (skonkretyzowanej) docelowej wizji rozwoju współpracy transgranicznej. Dotychczas formułowane wspólne dokumenty strategiczne/planistyczne były głównie złożeniem elementów istotnych z punktu widzenia poszczególnych regionów/ krajów związkowych bądź były bardzo ogólne. Brak wspólnego planowania strategicznego stanowi jeden z powodów trudności w rzeczywistym określeniu efektu transgranicznego oraz pomiaru skuteczności interwencji. Wskazuje to, że programy Interreg powinny być budowane na podstawie transgranicznych dokumentów strategicznych/planistycznych, formułowanych dla całego obszaru pogranicza.

Każdy obszar pogranicza jest unikatowy i niemożliwe jest stworzenie uniwersalnego i jednolitego w wymiarze UE katalogu wzorcowej interwencji. Dla jego określenia należy adaptować logikę interwencji, istniejącą w ramach programów regionalnych oraz przyjętą do kształtowania przestrzeni kraju, opartą na wyznaczaniu obszarów funkcjonalnych.

W celu poprawy efektu transgranicznego oraz realizacji postulatu koncentracji interwencji działania powinny być ukierunkowane terytorialnie. Należy w związku z tym zastosować podejście funkcjonalne do interwencji. Zasadniczą podstawą wydzielania obszarów funkcjonalnych powinno być to, aby ich zasięg obejmował obszary po obu stronach granicy. Konsekwencją będzie różnicowanie tematycznego wsparcia w zależności od zidentyfikowanych układów funkcjonalno-przestrzennych.

Interwencja powinna być wypadkową potrzeb i potencjałów terytorialnych. Z kolei możliwości precyzyjnego, kompleksowego i skutecznego zdefiniowania potrzeb lokalnych społeczności i wyznaczenia obszarów funkcjonalnych w oparciu o istniejące dokumenty strategiczne/planistyczne są dość ograniczone. Niezbędne jest zatem przeprowadzenie badań wyznaczających transgraniczne obszary funkcjonalne oraz identyfikujących potrzeby społeczności lokalnych w zakresie współpracy transgranicznej. 


\section{Literatura}

Boosting growth and cohesion in EU border regions. Communication from the Commission to the Council and the European Parliament, 2017, Brussels.

Ciok S., 1990, Problematyka obszarów przygranicznych Polski Poludniowo-Zachodniej. Studium społeczno-ekonomiczne, Acta Universitatis Wratislaviensis, nr 1155, Studia Geograficzne LXVIII, Warszawa-Wrocław.

Ciok S., 2004, Pogranicze polsko-niemieckie. Problemy wspótpracy transgranicznej, Acta Universitatis Wratislaviensis, nr 2603, Wydawnictwo Uniwersytetu Wrocławskiego, Wrocław.

Collecting solid evidence to assess the needs to be addressed by Interreg cross-border cooperation programmes. Final report, 2016, SWECO, t. 33, Politecnico di Milano, Nordregio, European Commission.

Comments by the German government on EU Cohesion Policy beyond 2020, 2017, Federal Ministry for Economic Affairs and Energy,.

Gruchman B., Nowińska-Łaźniewska E., Parowacz I., Kötzle A., Huskobla G., Osiecka A., 2002, Wspótpraca transgraniczna przedsiębiorstw na pograniczu polsko-niemieckim na przykładzie województw zachodniopomorskiego i lubuskiego oraz Landu Brandenburgii, Studia Regionalne i Lokalne, $\mathrm{nr} 4$ (10).

Koncepcja Przestrzennego Zagospodarowania Kraju 2030, 2012, MP, poz. 252.

Landesentwicklungsplan 2013, Sachsen.

Landesentwicklungsplan Berlin-Brandenburg (LEP B-B), 2017.

Landesraumentwicklungsprogramm Mecklenburg-Vorpommern (LEP M-V), 2016, Ministerium für Energie, Infrastruktur und Landesentwicklung, Greifswald.

Obrębalski M., 2011, Trójstyk 2020 - Perspektywy rozwoju pogranicza Saksonia - Pótnocne Czechy - Dolny Ślask, Friedrich Ebert Stiftung, Jelenia Góra.

People-to-people and small-scale projects in cross-border cooperation programmes. Draft opinion, 2017, Commission for Territorial Cohesion Policy and EU Budget, Brussels.

Powęska H., 2016, Handel przygraniczny w warunkach zmian przenikalności granicy, Wydawnictwo SGGW, Warszawa.

Przybyła Z., 1995, Problemy wspótpracy ekonomicznej regionów przygranicznych (na przykładzie euroregionu Nysa), Prace Naukowe Akademii Ekonomicznej, nr 708, Monografie i Opracowania, nr 113.

Przyszłość polityki spójności po 2020 r. Ku silnej i skutecznej europejskiej polityce spójności po $2020 \mathrm{r}$. Projekt opinii, 2016, Komisja Polityki Spójności Terytorialnej i Budżetu UE, Bruksela.

Raczyk A., Dołzbłasz S., Leśniak-Johann M., 2012, Relacje współpracy i konkurencji na pograniczu polsko-niemieckim, Gaskor, Wrocław.

Stasiak A., Miros K. (red.), 1993, Problematyka zachodniego obszaru pogranicza, IGiPZ PAN, Biuletyn $\mathrm{nr}$ 1, Warszawa.

Strahl D., Obrębalski M., 1995, Sieć osadnicza i ludność na terenie Euroregionu, Wiadomości Statystyczne, nr 3, Nysa.

Strategia na rzecz Odpowiedzialnego Rozwoju do roku 2020 (z perspektywą do 2030 r.), 2017, MP, poz. 260 , t. 1 .

Strategia Rozwoju Polski Zachodniej 2020, 2014, Rada Ministrów, Warszawa.

Strategia Rozwoju Województwa Dolnośląskiego 2020, UMWD, 2013, Wrocław.

Strategia Rozwoju Województwa Lubuskiego 2020, 2012, UMWL, Zielona Góra.

Strategia Rozwoju Województwa Zachodniopomorskiego 2020, 2010, UMWZ, Szczecin.

Stryjakiewicz T., 1998, The changing role of border zones in the transforming economies of East-Central Europe. The case of Poland, Geojournal, no 44 (3).

Studium integracji przestrzennej polskiej części pogranicza Polski i Niemiec, 2012, Ministerstwo Transportu, Budownictwa i Gospodarki Morskiej. 
Territories with specific geographical features, European Commission, DG REGIO, 2009, Working Paper, no 2.

Traktat o Unii Europejskiej i Traktatu o funkcjonowaniu Unii Europejskiej, 2012, Wersja skonsolidowana, C 326 , s. 0001-0390.

Węcławowicz G., Degórski M., Komornicki T., Korzeń J., Bański J., Korzeń J., Soja R., Śleszyński P., Więckowski M., 2006, Studia nad przestrzennym zagospodarowaniem obszaru wzdluż granicy polsko-niemieckiej, Prace Geograficzne, nr 207, IGiPZ PAN, Warszawa.

Wspólna Koncepcja Przyszłości dla polsko-niemieckiego obszaru powiązań. Wizja 2030, 2016, Komitet ds. Gospodarki Przestrzennej Polsko-Niemieckiej Komisji Międzyrządowej ds. Współpracy Regionalnej i Przygranicznej.

Wstępne stanowisko Rządu RP ws. polityki spójności po 2020 r., 2017. 